\title{
Comments on proper type designation for names of taxa validated by Turczaninow in his Animadversiones, with case studies
}

\author{
Sergei L. MOSYAKIN ${ }^{1}$, John McNEILL ${ }^{2}$, Ganna V. BOIKO ${ }^{1}$ \\ ${ }^{1}$ M.G. Kholodny Institute of Botany, National Academy of Sciences of Ukraine \\ 2 Tereschenkivska Str., Kyiv 01601, Ukraine \\ s_mosyakin@hotmail.com \\ bav22@ukr.net \\ ${ }^{2}$ Royal Botanic Garden Edinburgh, Edinburgh EH3 5LR, Scotland, U.K. \\ \& Royal Ontario Museum, Toronto, Canada \\ JMcNeill@rbge.org.uk
}

Mosyakin S.L., McNeill J., Boiko G.V. 2019. Comments on proper type designation for names of taxa validated by Turczaninow in his Animadversiones, with case studies. Ukrainian Botanical Journal, 76(5): 379-389.

Abstract. General recommendations regarding proper type designation of names of taxa described by Turczaninow in his Animadversiones series of articles (as well as in some other publications) are provided. It is concluded that, as clearly indicated in the protologues, all (or almost all) taxa described in these publications are based on specimens from the private herbarium of Turczaninow which was donated in the 1840s to the Kharkiv University (CWU) and in the 1940s was transferred to the Institute of Botany in Kyiv (KW). Consequently, holotypes and syntypes of these taxa are now almost exclusively in KW. Several cases of correct and incorrect type designations are discussed, specifically of some South American Brassicaceae, Geraniaceae and Hypericaceae, Central American Malvaceae, and southern African Polygalaceae. Information on the re-discovered holotype (KW) of Abelmoschus achanioides Turcz. (now accepted as Malvaviscus achanioides (Turcz.) Fryxell, Malvaceae) is provided, and an earlier lectotypification of that name with a specimen from G is considered ineffective. The holotype of Stenocalyx involutus Turcz. (now considered a synonym of Mezia includens (Benth.) Cuatrec., Malpighiaceae) was originally in the Turczaninow herbarium, but the whole folder with that specimen is now missing in KW (considered lost or destroyed), and it was already missing in the mid-1920s, when the collection was still in CWU. Because of that the lectotype of $S$. involutus is designated here, the specimen from MPU, to replace the lost or destroyed holotype. The need for thorough analysis of protologues, available original material, and associated information for correct type designation/indication is emphasized.

Keywords: bibliography, Brassicaceae, Geraniaceae, herbarium, Malpighiaceae, Malvaceae, nomenclature, Polygalaceae, taxonomy, type, typification

Submitted 31 July 2019. Published 31 October 2019

Мосякін С.Л. ${ }^{1}$, МакНіл Дж. ${ }^{2}$, Бойко Г.В. ${ }^{1}$ Нотатки про правильну типіфікацію назв таксонів, описаних М.С. Турчаніновим у серії статей "Animadversiones...", з кількома прикладами. Український ботанічний журнал, 76(5): 379-389.

${ }^{1}$ Інститут ботаніки ім. М.Г. Холодного НАН України

вул. Терещенківська 2, Київ 01004, Україна

2 Единбурзький Королівський ботанічний сад, Единбург ЕН3 5LR, Шотландія, Сполучене Королівство

Королівський музей Онтаріо, Торонто, Канада

Реферат. Наведені загальні рекомендації щодо правильного позначення типів назв таксонів, що були описані М.С. Турчаніновим у cepiï статей "Animadversiones..." (а також у деяких інших його публікаціях). На основі чітких вказівок у протологах зроблено висновок про те, що усі (або майже всі) таксони, описані в цих публікаціях, базуються на зразках з приватного гербарію Турчанінова, який у 1840-х роках був подарований ним Харківському університету (CWU), а у 1940-х роках переміщений до Інституту ботаніки у Києві (KW). Отже, голотипи та синтипи цих таксонів зараз знаходяться майже виключно у гербарії KW. Обговорюються декілька випадків правильних та неправильних позначень типів, зокрема, для деяких південноамериканських представників родин Brassicaceae, Geraniaceae та Hypericaceae, центральноамериканських Malvaceae та південноафриканських Polygalaceae. Наведена інформація про віднайдений у KW голотип Abelmoschus achanioides Turcz. (зараз визнаний під назвою Malvaviscus achanioides (Turcz.) Fryxell, Malvaceae), а попередня лектотипіфікація цієї назви зразком з гербарію G визнана недійсною. Голотип Stenocalyx involutus Turcz. (нині розглядається як синонім визнаної назви Mezia includens (Benth.) Cuatrec., Malpighiaceae) раніше знаходився у гербарії Турчанінова, але всієї папки з цим зразком у KW зараз немає; вона вважається втраченою і вже була відсутня у середині 1920 -х років, коли колекція ще перебувала в CWU. 3 цієї причини назва $S$. involutus лектотипіфікована тут зразком з гербарію MPU, на заміну втраченого або знищеного голотипу. Наголошується на необхідності ретельного аналізу протологів, наявного оригінального матеріалу та асоційованої інформації для правильної типіфікації.

Ключові слова: Brassicaceae, Geraniaceae, Malpighiaceae, Malvaceae, Polygalaceae, бібліографія, гербарій, номенклатура, систематика, тип, типіфікація

(C) 2019 S.L. Mosyakin, J. McNeill, G.V. Boiko. Published by the M.G. Kholodny Institute of Botany, NAS of Ukraine. This is an open access article under the terms of the Creative Commons Attribution License (http://creativecommons.org/licenses/by/4.0/), which permits use, distribution, and reproduction in any medium, provided the original work is properly cited

Український ботанічний журнал, 2019, 76(5) 


\section{Introduction}

Nikolai S. Turczaninow (1796-1863; Николай Степанович Турчанинов in Russian, Микола Степанович Турчанінов in Ukrainian, also sometimes transliterated as Turczaninov, Turchaninov, Turtschaninow, or Turczaninoff), despite his amateur background (professionally he was a government administrator), was a prolific plant taxonomist of the $19^{\text {th }}$ century who described numerous new taxa of plants from almost all parts of the world, especially Asia, South and Central America, southern Africa, and Australasia. Only a few species were described by him from Europe and North America north of Mexico. The number of plant names validated by Turczaninow is estimated at 172 genera and 1563 species (Myakushko, 1976; Myakushko et al., 1979; Shiyan, 2011), but these figures may be incomplete. The search in the IPNI database (https:// www.ipni.org/, accessed 16 May 2019) resulted in 4170 records (including nomenclatural combinations), but some of those records are duplicates.

Many new genera and species were described by Turczaninow in three articles of his Animadversiones series published in five issues of Bulletin de la Société Impériale des Naturalistes de Moscou (Turczaninow, $1855,1858 \mathrm{a}, 1858 \mathrm{~b}, 1859,1863)$. The complete bibliography is available from Stafleu and Cowan (1986: 541); however, there are several still remaining bibliographic problems. For example, the first article was probably released as a separate preprint in 1854 before its publication in the journal in 1855 . Sometimes these publications are cited incorrectly or incompletely, partly because of a specific and potentially confusing system of pagination used in volumes of the journal in the mid-19 $19^{\text {th }}$ century. In those times each volume of Bulletin... often consisted of two separately paginated parts, each with two issues ("numbers"). Thus, when citing publications in volumes of Bulletin de la Société Impériale des Naturalistes de Moscou with separate pagination of parts, it is important to indicate not just the issue number, but also the part number, and the issue and part numbers should not be confused. For example, the last article of the Animadversiones series (Turczaninow 1863) was published in part 1, issue 2 of volume 36 , but not in part 2, as it was erroneously indicated in Stafleu and Cowan (1986: 541).

Almost all new taxa described by Turczaninow in his Animadversiones articles were based, unless noted otherwise, on specimens from his personal herbarium that he donated in the late 1840 s to the Imperial Khar'kov [Kharkiv] University (now V.N. Karazin National University of Kharkiv, $\mathrm{CWU}^{1}$ ) in exchange for a modest annual pension from the University (unfortunately, soon cut down and then cancelled by the university authorities) and the possibility to continue his studies and curation of the herbarium. The fact that Turczaninow used exclusively (or almost exclusively) the specimens from his collection is properly reflected even in the titles of his articles: Animadversiones ad primam partem herbarii Turczaninowiani, nunc Universitatis Caesareae Charkowiensis (Turczaninow, 1855), Animadversiones in secundam partem herbarii Turczaninowiani, nunc Universitatis Caesareae Charkowiensis [Animadversiones Part 2, published in three issues] (Turczaninow, 1858a, 1858b, 1859), and Animadversiones ad catalogum primum et secundum herbarii Universitatis Charkowiensis [Addenda to Animadversiones Parts 1 and 2] (Turczaninow, 1863). Thus, Turczaninow in fact explicitly stated that his Animadversiones constitute an annotated catalogue of selected (most interesting from his viewpoint) specimens from his personal herbarium, since the $1840 \mathrm{~s}$ kept in CWU and in the 1940s transferred to KW.

The Turczaninow historical collection (informally referred to as KW-TURCZ) is now deposited at the National Herbarium of Ukraine in Kyiv (KW). It was transferred from Kharkiv (CWU) to Kyiv at the end of World War II (for history of the Turczaninow herbarium, see Myakushko, 1976; Myakushko et al., 1979; Marchant, 1990; Kamelin, Sytin, 1997; Shiyan, 2011; Mosyakin et al., 2018; and references therein). The specific circumstances of this transfer from CWU to KW remain insufficiently known.

The collection is kept separately from other KW collections and is estimated to contain at least 150000 (more probably 170000 or more) specimens representing ca. 53000 plant taxa from all parts of the Globe (see Shiyan (2011), and references therein). The exact number of specimens is difficult to estimate because the main part of the collection remains unmounted, kept as it was originally maintained by Turczaninow (which is important for maintaining the original arrangement of plant material and associated labels and folders for further research), and many sheets contain two or more specimens with associated labels.

${ }^{1}$ Herbarium acronyms are given following Index Herbariorum (Thiers 2008-onward).

Ukrainian Botanical Journal, 2019, 76(5) 
In the 1970s the curatorial staff of KWled by Taisia Ya. Myakushko [Omel'chuk-Myakushko] started activities aimed at inventory, cataloguing, and mounting of types of taxa validated by Turczaninow. By 1979 the managed and mounted part of the type collection contained ca. 1120 specimens, also systematized in a card catalogue. The plant families best represented in the catalogue were Myrtaceae (128 species), Asteraceae (109), Fabaceae (78), Verbenaceae (72), Sterculiaceae (62), Malvaceae (44), Tiliaceae (39), Rutaceae (39), Apocynaceae (38), Apiaceae (22), etc. (Myakushko et al., 1979, 1981).

Since then, additional type specimens were revealed and added to the type collection, and all these specimens were digitized and databased in the course of implementation of three projects supported by The Andrew W. Mellon Foundation during 2007-2016 within the framework of the African Plants Initiative, Latin American Plants Initiative, and the Global Plants Initiative. Now these digital images and associated data are available through JSTOR Global Plants (https:// plants.jstor.org), as well as other identified type specimens from $\mathrm{KW}$.

It should be noted that in older literature the Turczaninow types were often cited as definitely or supposedly held in St. Petersburg (LE) or Moscow (MW). Those herbaria indeed contain numerous specimens collected by Turczaninow, especially the main part of his Siberian collection, which is best represented in LE (see Lipschitz, Vasilchenko, 1968; Myakushko et al., 1979; etc.). The LE and MW herbaria also contain many duplicates of worldwide gatherings, specimens of which (those kept in his herbarium) were used by Turczaninow, but not the holotypes or syntypes of the names validated in Animadversiones and some other Turczaninow's publications; those holotypes and syntypes are now almost exclusively in KW. Seregin (2010: 71) commented on that as follows: "There is a misbelief (see, for instance, the web-version of Cyclopaedia of Malesian Collectors), that MW or/and LE possess Turczaninow's holotypes. In the case of MW this belief is largely based on the fact, that his protologues were published in Bulletin de la Société Impériale des Naturalistes de Moscou (this serial is still continued as Byulleten' Moskovskogo Obshchestva Ispytatelei Prirody, Otdel Biologicheskii). The personal collection of Turczaninow with numerous authentic specimens was conserved for a long time in the Kharkov University. Nazi decided to move this treasure to Germany as a war trophy in 1940s, but due to a logistic mistake the railway carriage had not arrived to the destination point. Turczaninow's herbarium was completely returned by restitution to Kiev soon after the end of World War II. Now this historic collection is conserved in the Kholodny Botanical Institute, Kiev (Ukraine) as a separate unit, and the holotypes should be searched for there" (see also comments in Mosyakin, de Lange, 2019).

Mosyakin and co-authors have already briefly discussed the problem of the type status of original specimens and type designation for plant names validated by Turczaninow in his Animadversiones, using the case of two names in Celastraceae considered in our proposal to conserve the name Tontelea attenuata Miers (1872: 384) against Maytenus amygdalina Turczaninow (1858b: 451) (Biral et al., 2019), and the cases of four taxa of Geraniaceae described by Turczaninow from New Zealand and Australia (Mosyakin, de Lange, 2019).

Here we provide general recommendations regarding type designation for the names published by Turczaninow, specifically those validated in his Animadversiones. These recommendations should not, however, be applied uncritically to taxa described by Turczaninow in his other publications in which no clear statement of the usage of specimens from his own herbarium was present, such as his Flora-BaicalensiDahurica [see details and bibliography in Stafleu (1969) and Stafleu and Cowan (1986)], and to taxa based on his own field collections in Siberia because it is documented that the author during that period of his activities widely shared his duplicates with many persons and institutions, and his original specimens are now present in many other herbaria, especially $\mathrm{G}$, LE, K, MW, etc. (see Stafleu, Cowan, 1986). Also, it is evident that, for example, in his Decas... series (e.g., Turczaninow, 1843, 1847, 1852, etc.; see bibliography in Stafleu, Cowan, 1986) Turczaninow used mainly or exclusively material from his herbarium; however, there is no explicit statement on that in the protologues, with some exceptions. For example, when describing Holopetalum pumilum Turczaninow (1843: 51) he cited "Reseda n. 7533 in Drège coll. pl. Capens.", and Drège collections from southern Africa are present in many herbaria. However, Turczaninow (1843: 52) also indicated that seeds in his specimens are immature ("Semina in speciminibus meis immatura"), which can be viewed as a reference to his herbarium. 
General guidelines for identification of the type status of original specimens and for typification of plant names validated by Turczaninow in his Animadversiones

The following general guidelines provide more detailed recommendations and are based on relevant provisions of Art. 9 of the ICN [here and below the ICN articles refer to the Shenzhen Code (Turland et al., 2018), unless noted otherwise], and also explanations and recommendations by McNeill (2014) specifically for holotypes.

(1) For all taxa described by Turczaninow in his Animadversiones and some other publications that were explicitly based, unless noted otherwise in the protologue, on specimens from Turczaninow's private herbarium donated first to CWU (in the 1840s) and then transferred to KW (in the 1940s), all (or almost all) types (holotypes or syntypes) are now in KW. Exceptions are very few, and for those exceptional cases Turczaninow usually clearly indicated that he has seen also specimens from other herbaria.

(2) If Turczaninow indicated or mentioned in the protologue just one specimen, and if there is just one corresponding specimen in KW-TURCZ, that specimen should be considered the holotype and that type designation is final (Art. 9.1 of the ICN).

(3) However, "the possibility that the author used additional, uncited specimens or illustrations (which may have been lost or destroyed) must always be considered" (Art. 9.1, Note 1 of the ICN). For such specific cases McNeill (2014: 1113), to ensure validity of type designations on or after 1 January 2001, recommended the following: "It is, therefore, wise for authors who are doubtful as to whether or not a particular specimen in one herbarium is the holotype to cite it as: "Lectotype, designated here (or perhaps holotype)". Thus, if Turczaninow indicated in the protologue just one gathering, and if there is just one corresponding extant specimen in KW-TURCZ, that specimen is most probably the holotype. If that KW specimen was cited/designated as the holotype, lectotype, or just "type" prior to 1 January 2001, that type designation should stand even if an additional original specimen or specimens studied by Turczaninow is/are found in KW. In that case the specimen first designated as the "holotype" or "type" should be corrected to "lectotype" following Art. 9.10 of the ICN. However, if no type designation for a particular Turczaninow's taxon has been made prior to 1 January 2001, it is possible (or in some cases even advisable) to cite the only existing original specimen from KW-TURCZ with the type designation as "Lectotype, designated here (or perhaps holotype)", following the recommendation of McNeill (2014).

(4) If Turczaninow indicated in the protologue one gathering but there are two or more corresponding specimens in KW-TURCZ, these specimens are syntypes (Art. 9.6 of the ICN). The lectotype should be selected preferably from these syntypes (Art. 9.11 and 9.12 of the ICN). However, if two or more corresponding sheets in KW-TURCZ have just one original label, are clearly cross-referenced (for example, as "Sheet 1" and "Sheet 2", or "I" and "II", or "a" and "b", etc.), and belong to one taxon (i.e., do not represent a mixed collection), they may constitute one specimen mounted on two or more sheets (Art. 8.2 and 8.3 of the ICN). Such cross-references, and often also additional curatorial labels (copies of original labels), were usually added by the curatorial staff of KW in the 1970s-1980s (and occasionally later) when the Turczaninow type specimens were pulled out from his mainly unmounted original collection, catalogued on paper cards, and mounted (see Myakushko et al., 1979). If there is just one original specimen in KW-TURCZ mounted on two or more sheets, that specimen is the holotype (but see paragraph (3) above). Examples of such type specimens mounted on two sheets are Maytenus amygdalina Turcz. (holotype on KW001001094 and KW001001095; see Biral et al., 2019) and Erodium peristeroides Turcz. (holotype on KW001001021 and KW001001022; see Mosyakin, de Lange, 2019).

(5) If Turczaninow indicated in the protologue two or more gatherings, all corresponding specimens in KWTURCZ are syntypes ( 9.6 of the ICN). The lectotype should be preferably selected from these syntypes (Art. 9.11 and 9.12 of the ICN). The possibility that one of the original gatherings present in KW-TURCZ is in fact one specimen mounted on two or more sheets should be also critically considered (see paragraph (4) above).

(6) If no original material (as defined in Art. 9.4 of the ICN) is currently present in the Turczaninow herbarium at KW (i.e. presumably lost or destroyed), a lectotype may be selected from other original material that is extant in other herbaria (usually isotypes or isosyntypes, i.e., duplicates of the types or syntypes indicated by Turczaninow in the protologue and belonging to the same gathering or gatherings). However, if the lost holotype is rediscovered, the lectotypification will have no standing because the holotype always takes precedence over a lectotype. 
(7) If no original material (as defined in Art. 9.4 of the ICN) is known to be present in the Turczaninow herbarium at KW and in other herbaria (i.e., if all original material is presumably lost or destroyed), a neotype may be selected (Art. 9.8 and 9.13 of the ICN). However, a neotype serves as the nomenclatural type only as long as original material is missing. If any part of the original material is found to exist (rediscovered), a lectotype should be designated from it because a lectotype always takes precedence over a neotype [Art. 9.13 of the ICN, except as provided by Art. 9.16 and 9.19(c)].

Consequently, any lectotype of a Turczaninow's taxon name validated in Animadversiones (as well as in some other publications by Turczaninow) that was designated by any author not from specimens housed at KW-TURCZ but from another herbarium without considering Turczaninow specimens will have no standing if it is demonstrated that the holotype ("the one specimen... either $(a)$ indicated by the author(s) as the nomenclatural type or $(b)$ used by the author(s) when no type was indicated"; Art. 9.1 of the ICN) of that taxon is extant in KW. If there are two or more syntypes in $\mathrm{KW}$, a lectotype should be preferably selected from those syntypes.

However, the current wording of Art. 9.12 of the ICN makes syntypes and isosyntypes in fact equal in lectotype designation: "In lectotype designation, an isotype must be chosen if such exists, or otherwise a syntype or isosyntype if such exists". Thus, formally, if an isosyntype from some herbarium (but not a syntype from KW) has been designated by some author(s) as a lectotype of Turczaninow's taxon described in Animadversiones, that designation should stand. In our opinion, the specimens cited in the protologue (syntypes; see Art. 9.6) should be always preferred in lectotype designation over uncited specimens (isosyntypes; see Art. 9.4, footnote).

It would be also advisable to formalize that provision in the next edition of the Code and to ensure that a syntype should always take precedence over an isosyntype. In our opinion, it can be achieved through a proposal to amend the first sentence of Art. 9.12 of the ICN as follows: "In lectotype designation, an isotype must be chosen if such exists, or otherwise a syntype if such exists, or otherwise an isosyntype if such exists" (as compared to the current wording: "In lectotype designation, an isotype must be chosen if such exists, or otherwise a syntype or isosyntype if such exists"). The relevant proposal to amend the Code has been prepared, and it will be formally submitted as soon as the procedures and timetable are published in Taxon (expected late 2019 or early 2020).

Thus, we urge all plant taxonomists working on type designation for taxa described by Turczaninow (especially those validated in his Animadversiones series definitely and explicitly based on his private herbarium, now in $\mathrm{KW}$ ) to consult first the specimens available in KW-TURCZ and/or their digital images (mainly available from JSTOR Global Plants: https://plants. jstor.org).

Additional explanation should be provided for specific cases of lectotypification of taxa validated by Turczaninow. If in KW-TURCZ there is just one original specimen of a particular Turczaninow's taxon originally described in the protologue with an indication of Turczaninow's herbarium, that specimen is most probably the holotype (see details above). However, both before and after 1 January 2001 lectotypifications of names with such specimens are not erroneous (see the South American Geranium case discussed below).

Consequently, for the cases considered above, all duplicates of the KW holotypes (or probable holotypes that were indicated or designated as lectotypes by typifying authors) belonging to the same gathering but housed in other herbaria are in fact isotypes (or isolectotypes, if formal lectotypifications based on KW specimens have been done).

Taking into consideration the above arguments, we provide below the nomenclatural examples (with some corrected typifications) for selected plant names validated by Turczaninow in his Animadversiones.

\section{Selected case studies}

\section{Brassicaceae: South American Draba}

An example of the correct type designation/indication of Turczaninow's plant names is the recent treatment of South American taxa of Draba Linnaeus (1753: 642) by Al-Shehbaz (2018), who in all cases accepted unique specimens from KW-TURCZ as holotypes of the names validated by Turczaninow (1855). However, if, for any particular taxon of Draba currently represented in KWTURCZ by just one specimen, any additional original specimen definitely studied by Turczaninow is found in KW (which is rather improbable), lectotypification will be necessary because the holotype indication was made by Al-Shehbaz (2018) after 1 January 2001, and there is currently no option in the ICN for automatic correction of the indication of a supposed holotype to the designation of a lectotype, unless the words "designated here", "hic designatus", or an equivalent 
(Art. 7.11 and Art. 9 Note 6 of the ICN) were used by the typifying author after 1 January 2001 (see McNeill, 2014).

\section{Geraniaceae: South American Geranium}

Four currently recognized South American taxa of Geranium described by Turczaninow (1858b) were lectotypified by Aedo et al. (2003; see also Aedo, 2012) with the specimens from KW, based on images (photographs) studied. For each of these four names, only one original specimen currently exists in the Turczaninow herbarium, and thus these four specimens can be considered holotypes of the four names. These lectotype designations with the words "here designated" made by Aedo et al. (2003) instead of indications of holotypes are, however, acceptable and correct under the current Shenzhen Code (Turland et al., 2018), as they were also under the previous Melbourne Code (McNeill et al., 2012; see also McNeill, 2014) and earlier Codes. Digital images of these four lectotypes (or, in fact, holotypes cf. Art. 9.1 and 9.10 of the ICN) of Geranium names are now available online from JSTOR Global Plants: Geranium lindenianum Turczaninow (1858b: 417; https://plants.jstor.org/stable/10.5555/al.ap.specimen. kw001000002); G. multiceps Turczaninow (1858b: 417; https://plants.jstor.org/stable/10.5555/al.ap. specimen.kw001000001); G. subnudicaule Turczaninow (1858b: 418; https://plants.jstor.org/stable/10.5555/ al.ap.specimen.kw001001017), and $\boldsymbol{G}$. velutinum Turczaninow (1858b: 417; https://plants.jstor.org/ stable/10.5555/al.ap.specimen.kw001001018).

\section{Malpighiaceae: Stenocalyx involutus}

The generic name Stenocalyx Turczaninow (1858b: 393) and the species name Stenocalyx involutus Turczaninow (1858b: 394) were validated by a single description (descriptio generico-specifica, Art. 38.5 of the ICN; Turland et al., 2018).

Unfortunately, the generic name proposed by Turczaninow is a latter homonym of Stenocalyx O.Berg (1856: 309) belonging to Myrtaceae, and thus the currently accepted name for the genus of Malpighiaceae proposed by Turczaninow as Stenocalyx is Mezia Schwacke ex Niedenzu (1890: 58); see further taxonomic and nomenclatural details in C. Anderson and W.R. Anderson (2018) and Cuatrecasas and Croat (1980).

The following provenance was cited for Stenocalyx involutus in the protologue: "In provincia Caraboba Venezuelae, prope St.-Estevan, alt. 1000 ped. Funck et Schlim n. 518". Judging from the handwritten
Turczaninow's catalogue of his herbarium currently held at KW (see Diachenko et al., 2015), the corresponding specimen (or specimens?) was (were) held in Folder 83. However, this whole folder is missing, and it was already missing in 1924-1925, when an inventory of the Turczaninow herbarium has been done in CWU by E.M. Lavrenko and others (Diachenko et al., 2015: 276, 278).

C. Anderson and W.R. Anderson (2018: 355) assumed that the type of Stenocalyx involutus is deposited in KW (which is not the case, as reported above) and provided the following type information: "Type: Venezuela, Carabobo, 'St. Estevan' [San Esteban, $10^{\circ} 26^{\prime} \mathrm{N}$, $68^{\circ} 00^{\prime} \mathrm{W}$ ], 1845-46, Funck \& Schlim 518 (holo KW?; iso G, MPU*)".

Thus, they indicated the presence of other original specimens in herbaria of Geneva and Montpellier, and, since the holotype from KW cited by Turczaninow is lost or destroyed, a lectotype should be selected from other extant original material (Art. 9.12 of the ICN), in that case an isotype (or isosyntype). We thus designate here the specimen from MPU (barcode MPU021273) as the lectotype of Stenocalyx involutus.

Mezia includens (Benth.) Cuatrecasas (1958: 450) $\equiv$ Tetrapterys includens Bentham (1848: 133) $\equiv$ Diplopterys includens (Benth.) Niedenzu (1928: 226).

Type: FRENCH GUIANA: 'Cayenne': Martin s.n. K -

Bentham Herbarium [vide Anderson and Anderson (2018: 355$)$, cited as the holotype; isotype in $\mathrm{K}-$ Hooker Herbarium], non vidi.

= Stenocalyx involutus Turczaninow (1858b: 394) $\equiv$ Diplopterys involuta (Turcz.) Niedenzu (1928: 226).

Type: VENEZUELA: "No. 518 | Stenocalyx involutus

| Turczan. [identification probably added later, in another hand] | fl. jaunes | San Estevan (Caraboba) | Funcke [Funck] \& Schlim | Coll. 1845-6", MPU, barcode MPU021273 (lectotype, designated here to replace the lost or destroyed holotype originally held at CWU; image available from https://plants.jstor. org/stable/10.5555/al.ap.specimen.mpu021273 and https://herbier.umontpellier.fr/zoomify/zoomify. php?fichier=MPU021273).

\section{Malvaceae from Central America}

Dorr (2017: 25) cited the following type information for the name Cybiostigma sidifolium Turczaninow (1852: 155, as "sidaefolium"), the basionym of the currently accepted name Ayenia sidifolia (Turcz.) Hemsley (1979: 135): "Cybiostigma sidifolium Turcz., Bull. Soc. Imp. Naturalistes Moscou 25(3):155. 1852. Ayenia 
mexicana Turcz., Bull. Soc. Imp. Naturalistes Moscou 36(2):569. 1863, nom. superfl. Type: Mexico. Oaxaca: savannah near the Pacific, $3000 \mathrm{ft}, 1840$ (fl), H. Galeotti 326 (lectotype, as "tipo" designated by Cristobal 1960: G [G00358304 as image!]; isolectotypes: BR [BR0000005423101 as image!], K [K000543778]!, K [K000543779]!, KW [KW001000156 as image!], $\mathrm{P}$ [P02286136 as image!])".

Thus, he accepted the type (in fact, the lectotype, image available from https://plants.jstor.org/ stable/10.5555/al.ap.specimen.g00358304) designated by Cristóbal (1960), and formally did it correctly, even despite the fact that the unique original specimen studied and annotated by Turczaninow is present in KW (image available from https://plants.jstor.org/ stable/10.5555/al.ap.specimen.kw001000156), because there was no explicit indication of a particular specimen or herbarium in the protologue (one of Turczaninow's Decas... articles, see above). However, this case is not the best typification practice: the KW specimen was evidently the best option for designation of a lectotype because it bears the annotation by Turczaninow, belonged to his personal herbarium, and was definitely studied by him.

Fryxell (1979: 253) proposed a new combination Malvaviscus achanioides (Turcz.) Fryxell based on Abelmoschus achanioides Turczaninow (1858a: 196) and cited the type as deposited in Geneva: "Linden 838 [938] ( $\mathrm{G}$ as photo NY)". Indeed, the G herbarium has two supposedly original specimens (one mounted on two sheets) of probably the same gathering, but with the collection number reported as Linden 9381, and/or 938 on an envelope on one sheet (images available from https://plants.jstor.org/stable/10.5555/al.ap.specimen. g00353129 and https://plants.jstor.org/stable/10.5555/ al.ap.specimen.g00353130). However, the holotype (Fig. 1) was recently found by the first author (Sergei Mosyakin) in the general unmounted part of the Turczaninow collection in KW; it is well preserved and rather complete (a branch with four leaves, one flower, and buds). That specimen has not been added earlier to the collection of mounted types, most probably because Turczaninow's original identification "Abelmoschus achanioides Turcz." was written directly on the folder but not on a label. Such identifications on the folder only were sometimes practiced by Turczaninow, especially during later years of his life. The collection number on the original label is clearly given as Linden 838 , exactly as in the protologue. It is thus definitely the one specimen cited in the protologue. The proper type designation is provided below.
Malvaviscus achanioides (Turcz.) Fryxell (1979: 253)

$\equiv$ Abelmoschus achanioides Turczaninow (1858a: 196)

三 Hibiscus achanioides (Turcz.) Hemsley (1879: 121).

Type: MEXICO: "Hibiscus | [shrub sign] fl. rouge | forêt de Teapa | Mexique, Etat de Tabasco | Hauteur 2000 p [feet] | 1839 Linden 838", KW, barcode KW001003068 (holotype), Fig. 1.

Several other holotypes and syntypes of Turczaninow's Malvaceae that were previously considered lost (e.g., see the list in Fryxell, Krapovickas, 1990) have been recently re-discovered by Sergei Mosyakin and Ganna Boiko among unmounted specimens in the Turczaninow Herbarium (KWTURCZ), including the holotypes of Malva mathewsii Turczaninow (1863: 563), M. scorpioides Turczaninow (1863: 562), and Sphaeralcea galeottii Turczaninow (1858a: 186). These and some other type specimens of Malvaceae newly found in the Turczaninow Herbarium will be considered in a special article.

\section{Polygalaceae: southern African Polygala}

In their checklist of southern African taxa of Polygala Linnaeus (1753: 701), Figueiredo et al. (2013) correctly indicated the types (holotypes) of Turczaninow's taxa as deposited in KW and corrected the earlier type (lectotype) designation made by Paiva (1998) for the name $\boldsymbol{P}$. ciliatifolia Turczaninow (1855:347) [considered a synonym of $P$. umbellata L.: Linnaeus (1771: 259)] to the holotype in KW (KW001000268, image available from https://plants.jstor.org/stable/10.5555/al.ap. specimen.kw001000268): "Although Paiva designated the M specimen as lectotype (Paiva 1998: 271), it is considered that all types of Turczaninow are at Kiew (KW), Ukraine" (Figueiredo et al. 2013: 5). As we discussed above, not all types of Turczaninow are in Kyiv, but those of almost all taxa described in Animadversiones (including P. ciliatifolia) are certainly at KW.

\section{Hypericaceae: South American Hypericum}

In his taxonomic treatment of Hypericum L. (Linnaeus, 1753: 783) sect. Brathys (L. fil.) Choisy (1821: 58) [= Brathys L.f. (Linnaeus fil., 1782: pl. 43, 268)], Robson (1987) in all cases indicated the types of the names validated by Turczaninow as deposited in LE (as four holotypes and one lectotype). In fact, all these taxa were published in Animadversiones (Turczaninow, $1858 \mathrm{~b}$ ) and their types (holotypes, or syntypes if two or more specimens or gatherings were indicated in the protologue) are in KW-TURCZ. Images of most of these KW specimens of Hypericum are available online from 


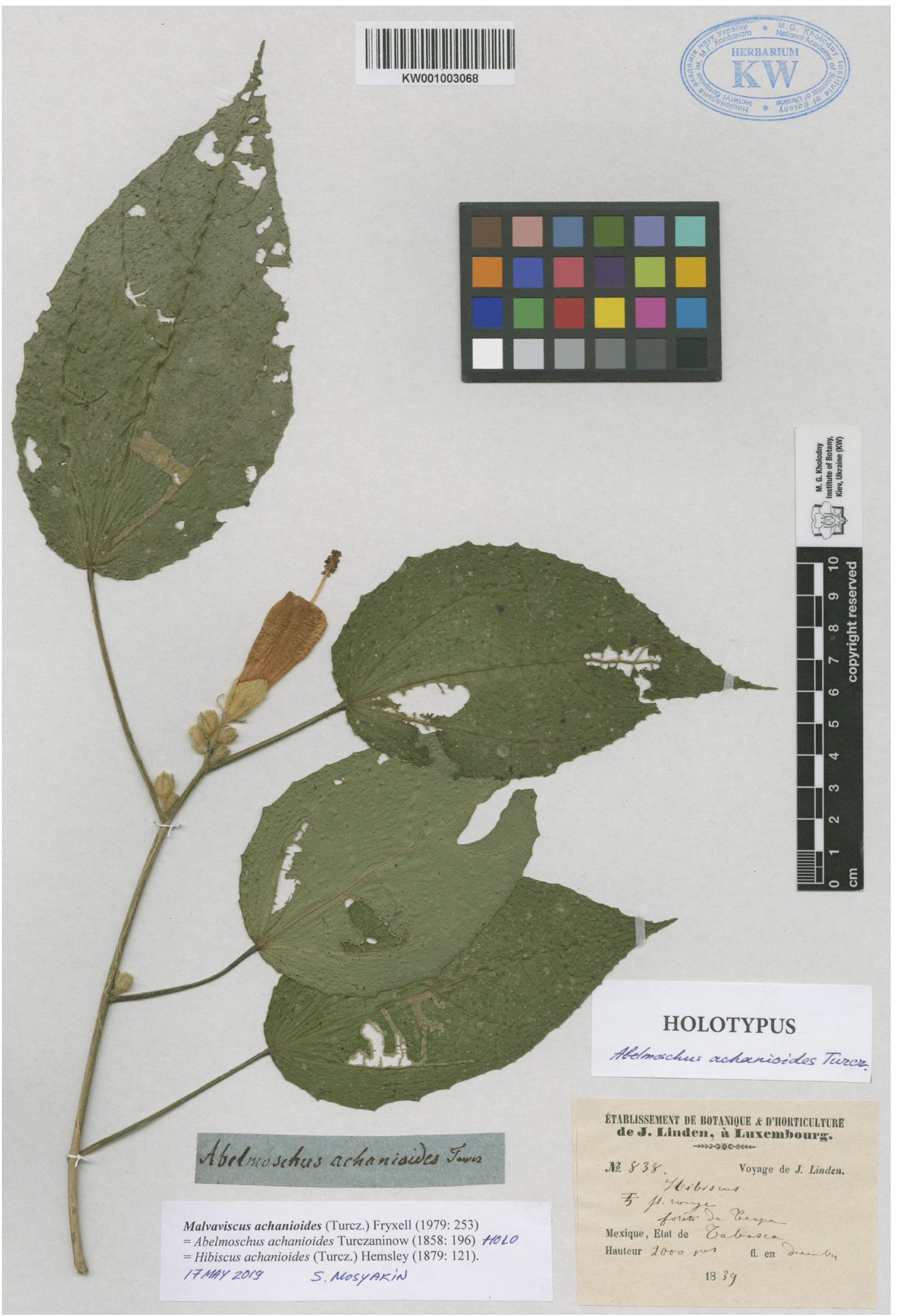

Figure. Holotype of Abelmoschus achanioides Turcz. (KW001003068), now accepted as Malvaviscus achanioides (Turcz.) Fryxell. 
JSTOR Global Plants, with some exceptions of a few supposedly missing specimens. We were able to locate recently these previously unaccounted specimens in the unmounted part of the Turczaninow collection, and the herbarium citations with corrected typifications will be published in a separate nomenclatural note (Mosyakin et al., in preparation).

\section{Concluding remarks}

Many additional examples of correct and incorrect indications or designations of types of plant names validated by Turczaninow in his Animadversiones and in some other publications can be provided. Some specific cases will be discussed in more detail in forthcoming articles. In any case, a critical analysis of the protologue, available original material, and associated information is crucial for correct type designation/indication for Turczaninow's names, as well as names published by any other author. It is much easily done now than it used to be before, mainly because of the growing online availability of digitized protologues and herbarium specimens.

\section{Acknowledgements}

We are grateful to Rafaël H.A. Govaerts and Nicholas Black (Royal Botanic Gardens, Kew, U.K.) for providing datasets of Turczaninow's plant names from the Plants of the World Online database, to Carlos Aedo (Real Jardín Botánico, Madrid, Spain) and Ihsan A. Al-Shehbaz (Missouri Botanical Garden, St. Louis, MO, U.S.A.) for providing copies of their important publications, to Peter J. de Lange (Unitec Institute of Technology, Auckland, New Zealand) for discussing the cases of taxa of Geraniaceae described by Turczaninow from New Zealand and Australia, to Leonardo Biral (Universidade Tecnológica Federal do Paraná, Santa Helena, Paraná, Brazil) for discussing some Turczaninow's names in Celastraceae from South America; and to Natalia M. Shiyan (Head Curator, KW), Alisa V. Shumilova, Iryna I. Diachenko (Curatorial Assistants, KW), and Svitlana I. Antonenko (KW, M.G. Kholodny Institute of Botany, National Academy of Sciences of Ukraine, Kyiv, Ukraine) for facilitating our herbarium research at KW. The generous support of The Andrew W. Mellon Foundation provided in 2007-2016 for digitization of type specimens at $\mathrm{KW}$ is greatly appreciated.

\section{REFERENCES}

Aedo C. 2012. Revision of Geranium (Geraniaceae) in the New World. Systematic Botany Monographs, 95: 1-550.

Aedo C., Aldasoro J.J., Sáez L., Navarro C. 2003. Taxonomic revision of Geranium sect. Gracilia (Geraniaceae). Brittonia, 55: 93-126.

Al-Shehbaz I.A. 2018. A monograph of the South American species of Draba (Brassicaceae). Annals of the Missouri Botanical Garden, 103(4): 463-590. https://doi. org/10.3417/2018184

Anderson C., Anderson W.R. 2018. Revision of Mezia (Malpighiaceae). Edinburgh Journal of Botany, 75(3): 321-376. https://doi.org/10.1017/S096042861800015X

Bentham G. 1848. Contributions to the Flora of Guiana. Enumeration of plants collected in British, Dutch, and French Guiana, by Sir Robert and Richard Schomburgk, Dr. Hostmann, M. Leprieur, and others [Part 1]. London Journal of Botany, 7: 116-137.

Berg O. 1856. Revisio myrtacearum americae. Linnaea, 27: $1-472$.

Biral L., Mosyakin S.L., Lombardi J.A. 2019. Proposal to conserve the name Tontelea attenuata (Celastraceae) against Maytenus amygdalina. Taxon, 68(4) (in press).

Choisy J.D. 1821. Prodromus d'une monographie de la famille des hypéricinées. Genève: J.J. Paschoud; Paris: Mème maison de Commerce, ii + 70 pp. + IX tab.

Cristóbal C.L. 1960. Revisión del género Ayenia (Sterculiaceae). Opera Lilloana, 4: 1-230.

Cuatrecasas J. 1958. Prima Flora Colombiana: 2. Malpighiaceae. Webbia, 13(2): 343-664. https://doi.org/10.1080/0 0837792.1958 .10669680

Cuatrecasas J., Croat T.B. 1980. Malpighiaceae [in Woodson R.E., Schery R.W. \& collaborators (Eds.) Flora of Panama, Part VI]. Annals of the Missouri Botanical Garden, 67: 851-945.

Diachenko I.I., Shumilova A.V., Shiyan N.M. 2015. The Catalogue of the herbarium collection of M.S. Turczaninow as a unique scientific and historical manuscript. In: Contribution of amateur naturalists into biological diversity studies. International Scientific Conference devoted to the 200' anniversary of Lajos Vágner's birthday. Beregovo; Uzhgorod: Ferenc Rákóczi II Transcarpathian Hungarian Institute, pp. 274-279. [Дяченко I.I., Шумілова А.В., Шиян Н.М. 2015. Каталог гербарної колекції М.С. Турчанінова - унікальна рукописна науково-історична пам'ятка. В зб.: Внесок натуралістів-аматорів у вивчення біологічного різноманіття. Матеріали міжнародної наукової конференції, присвяченої 200-річчю від дня народження Людвіга Вагнера (14-16 травня 2015 року, Берегово, Украӥна). Берегово; Ужгород: Закарпатський угорський інститут ім. Ф. Ракоці II, с. 274-279].

Dorr L.J. 2017. Two innovations in Mexican Malvaceae. Journal of the Botanical Research Institute of Texas, 11(1): 25-28.

Figueiredo E., Smith G.F., Pavia J. 2013. A checklist of Polygala (Polygalaceae) in the Flora of Southern Africa region with notes on types. Phytotaxa, 155(1): 1-22. http://dx.doi.org/10.11646/phytotaxa.155.1.1 
Fryxell P.A. 1979. Taxonomic notes on Chiapas Malvaceae. Systematic Botany, 4(3): 253-256.

Fryxell P.A., Krapovickas A. 1990. The Malvaceae published by Turczaninow. Contributions from the University of Michigan Herbarium, 17: 173-182.

Hemsley W.B. 1879. Malvaceae, Sterculiaceae. In: Hemsley W.B. Biologia Centrali-Americana; or, contributions to the knowledge of the fauna and flora of Mexico and Central America edited by F. Ducane Godman and Osbert Salvin. Botany, vol. 1(2). London: R.H. Porter \& Dulau \& Co., pp. 98-136.

Kamelin R.V., Sytin A.K. 1997. Nikolai Stepanovich Turchaninow (on the occasion of his bicentenary). Botanicheskiy Zhurnal, 82(9): 123-137. [Камелин Р.В., Сытин А.К. 1997. Николай Степанович Турчанинов (к 200-летию со дня рождения). Ботанический журнал, 82(9): 123-137].

Linnaeus C. 1753. Species Plantarum, vols. 1-2. Holmiae [Stockholm]: Laurentius Salvius, 1200 pp.

Linnaeus C. 1771. Mantissa Plantarum [vol. 2] Altera, Generum editionis VI \& Specierum editionis II. Holmiae [Stockholm]: Impensis Direct. Laurentii Salvii, pp. 143-588.

Linnaeus C. fil. 1782 (dated "1781"). Supplementum Plantarum Systematis Vegetabilium editionis decimae tertiae, Generum Plantarum editionis sextae, et Specierum Plantarum editionis secundae. Brunsvigae [Braunschweig]: Impensis Orphanotrophei, [14 pp. Praefatio] + 468 pp.

Lipschitz S.Yu., Vasilchenko I.T. 1968. Central herbarium of the USSR. Leningrad: Nauka, 141 pp. [Липшиц С.Ю., Васильченко И.Т. 1968. Центральный гербарий СССР. Ленинград: Наука, 141 с.].

Marchant N.G. 1990. The contribution of the Russian botanist Turczaninov to Australian plant taxonomy. In: Short P.S. (Ed.). History of Systematic Botany in Australasia. Proceedings of a symposium held at the University of Melbourne 25-27 May 1988. Canberra: ASBS, pp. $121-130$.

McNeill J. 2014. Holotype specimens and type citations: general issues. Taxon, 63(5): 1112-1113.

McNeill J., Barrie F.R., Buck W.R., Demoulin V., Greuter W., Hawksworth D.L., Herendeen P.S., Knapp S., Marhold K., Prado J., Prud'homme van Reine W.F., Smith G.F., Wiersema J.H., Turland N.J. (Eds.). 2012. International Code of Nomenclature for algae, fungi, and plants (Melbourne Code): Adopted by the Eighteenth International Botanical Congress, Melbourne, Australia, July 2011. Königstein: Koeltz Scientific Books. Regnum Vegetabile, 154: 1-274.

Miers J. 1872. On the Hippocrateaceae of South America. Transactions of the Linnean Society of London, 28: 319-432.

Mosyakin S.L., de Lange P.J. 2019. Notes on typification and nomenclature of four taxa of Geraniaceae described by Turczaninow from New Zealand and Australia. Phytotaxa, 419(2): 169-181.http://dx.doi.org/10.11646/ phytotaxa.419.2.3

Mosyakin S.L., Esser H.-J., Freitag H. 2018. The holotype of Chenopodium baryosmon (Chenopodiaceae) rediscovered: just one of many type specimens from the private herbarium of Schultes, now in the Turczaninow herbarium at KW. Phytotaxa, 334(1): 49-54. http:// dx.doi.org/10.11646/phytotaxa.334.1.7

Myakushko T.Ya. 1976. The scientific heritage of M.S. Turchaninov. Ukrainian Botanical Journal (Ukrayins'kyi Botanichnyi Zhurnal), 33(6): 647-651. [М'якушко Т.Я. 1976. Наукова спадщина М.С. Турчанінова. Український ботанічний журнал, 33(6): 647-651].

Myakushko T.Ya., Glagoleva N.G., Mel'nyk S.K. 1979. M.S. Turchaninov's herbarium collection of type specimens of new species. Ukrainian Botanical Journal (Ukrayins'kyi Botanichnyi Zhurnal), 36(1): 85-90. [М'якушко Т.Я., Глаголєва Н.Г., Мельник С.К. 1979. Гербарна колекція типових зразків нових видів М.С. Турчанінова. Український ботанічний журнал, 36(1): 85-90].

Myakushko T.Ya., Sirenko I.P., Glagoleva N.G., Mel'nyk S.K. 1981. Information and search system of the herbarium collection of type specimens of M.S. Turchaninov's new taxa Ukrainian Botanical Journal (Ukrayins'kyi Botanichnyi Zhurnal), 38(4): 71-73. [М'якушко Т.Я., Сіренко І.П., Глаголева Н.Г., Мельник С.К. Інформаційно-пошукова система гербарної колекції типових зразків новоописів М.С. Турчанінова. Украӥнський ботанічний журнал, 38(4): 71-73].

Niedenzu F. 1890. Malpighiaceae. In: Engler A., Prantl K. (Eds.). Die natürlichen Pflanzenfamilien, Teil III, Abt. 4. Leipzig: W. Engelmann, pp. 41-74.

Niedenzu F. 1928. Malpighiaceae [Pars 1]. In: Engler A. (Ed.). Das Pflanzenreich, IV, 141, Heft 91. Leipzig: Verlag von Wilhelm Engelmann, pp. 1-246.

Paiva J.A.R. 1998. Polygalarum africanarum et madagascariensium prodromus atque gerontogaei generis Heterosamara Kuntze, a genere Polygala L. segregati et a nobis denuo recepti, synopsis monographica. Fontqueria, 50: i-vi + 1-346.

Robson N.K.B. 1987. Studies in the genus Hypericum L. (Guttiferae) 7. Section 29. Brathys (part 1). Bulletin of the British Museum (Natural History). Botany, 16: 1-106.

Seregin A.P. 2010. Collection of Hugh Cuming in the Moscow University Herbarium (MW). Komarovia, 7(12): 69-88.

Shiyan N.M. (Ed.). 2011. Herbaria of Ukraine. Index Herbariorum Ucrainicum, Kyiv: Alterpress, 442 pp. [Шиян Н.М. (ред.-укл.). 2011. Гербарії України. Index Herbariorum Ucrainicum. Київ: Альтпрес, 442 с.].

Stafleu F.A. 1969. Turczaninow's Flora Baicalensi-Dahurica. Taxon, 8(5): 563-565. Available at: https://www.jstor. org/stable/1218386

Stafleu F.A., Cowan R.S. 1986. Taxonomic literature: A selective guide to botanical publications and collections with dates, commentaries and types, vol. 6: Sti-Vuy. $2^{\text {nd }}$ ed. Utrecht/Antwerpen: Bohn, Scheltema \& Holkema \& The Hague/Boston: dr. W. Junk b.v., Publishers, 926 pp.

Thiers B. 2008-onward. Index Herbariorum. A global directory of public herbaria and associated staff. New York Botanical Garden's Virtual Herbarium. Available at: http:// sweetgum.nybg.org/science/ih (Accessed 16 May 2019). 
Turczaninow N.S. 1843. Decas generum plantarum hucusque non descriptorum. Bulletin de la Société Impériale des Naturalistes de Moscou, 16 (No. 1): 51-62.

Turczaninow N.S. 1847. Decas tertia generum adhuc non descriptorum, adjectis descriptionibus nonnularum specierum Myrtacearum xerocarpicarum atque Umbelliferarum imperfectarum. Bulletin de la Société Impériale des Naturalistes de Moscou, 20 (Part 1, No. 1): 148-174.

Turczaninow N.S. 1852. Decas septima generum adhuc non descriptorum, adjectis descriptionibus nonnularum specierum. Bulletin de la Société Impériale des Naturalistes de Moscou, 25 (Part 2, No. 3): 138-181.

Turczaninow N.S. 1855 (volume of "1854"). Animadversiones ad primam partem herbarii Turczaninowiani, nunc Universitatis Caesareae Charkowiensis [Animadversiones Part 1]. Bulletin de la Société Impériale des Naturalistes de Moscou, 27 (Part 2, No. 4): 271-372.

Turczaninow N.S. 1858a. Animadversiones in secundam partem herbarii Turczaninowiani, nunc Universitatis Caesareae Charkowiensis [Animadversiones Part 2/1]. Bulletin de la Société Impériale des Naturalistes de Moscou, 31 (Part 1, No. 1): 185-250.
Turczaninow N.S. 1858b. Animadversiones in secundam partem herbarii Turczaninowiani, nunc Universitatis Caesareae Charkowiensis [Animadversiones Part 2/2]. Bulletin de la Société Impériale des Naturalistes de Moscou, 31 (Part 1, No. 2): 379-476.

Turczaninow N.S. 1859. Animadversiones in secundam partem catalogi plantarum herbarii Universitatis Charkowiensis [Animadversiones Part 2/3]. Bulletin de la Société Impériale des Naturalistes de Moscou, 32 (Part 1, No. 1): 258-277.

Turczaninow [as"Turczaninoff"] N.S. 1863. Animadversiones ad catalogum primum et secundum herbarii Universitatis Charkowiensis [Addenda to Animadversiones Parts 1 and 2]. Bulletin de la Société Impériale des Naturalistes de Moscou, 36 (Part 1, No. 2): 545-615.

Turland N.J., Wiersema J.H., Barrie F.R., Greuter W., Hawksworth D.L., Herendeen P.S., Knapp S., Kusber W.-H., Li D.-Z., Marhold K., May T.W., McNeill J., Monro A.M., Prado J., Price M.J., Smith G.F. (Eds.). 2018. International Code of Nomenclature for algae, fungi, and plants (Shenzhen Code) adopted by the Nineteenth International Botanical Congress Shenzhen, China, July 2017. Glashütten: Koeltz Botanical Books. Regnum Vegetabile, 159: xxxviii + 254 pp. https://doi. org/10.12705/Code. 2018

Recommended for publication by Ya.P. Didukh 